\title{
In vitro Metabolism of Tryptophan by Rumen Microorganisms : The Interrelationship between Mixed Rumen Protozoa and Bacteria
}

\author{
Katsuya OKunchi, Takashi Nagasawa*, \\ Yoshifumi TOMITA and Ryoji OnODERA \\ Animal Nutrition and Biochemistry, Animal Science \\ Division, Faculty of Agriculture, Miyazaki \\ University, Miyazaki-shi 889-21
}

(Received August 24, 1992)

\begin{abstract}
An in vitro study was conducted to examine the metabolism of tryptophan (Trp) via mixed rumen protozoa (P suspension), mixed rumen bacteria (B suspension) and their combination (BP suspension) using Trp, indolepyruvic acid (IPA) and indoleacetic acid (IAA) as substrates. Rumen microorganisms were collected from fistulated goats fed lucerne cubes and formula feed twice a day. During a 12-h incubation period, a large amount of Trp was produced from IPA and accumulated in the medium in $\mathrm{P}$ suspensions, but not from IAA. Even in B and BP suspensions, Trp must have been synthesized from IPA, but it was not accumulated in the media, probably because of its consumption for growth of the microorganisms. IAA was produced in large quantities from Trp and IPA in B and BP suspensions, but only in small quantities in $\mathrm{P}$ suspensions. Skatole (Skt) equivalent to $31.9 \%$ of added Trp was produced from the amino acid during a 12-h incubation period in BP suspensions, in spite of the fact that Skt was hardly produced and not produced from Trp in $B$ and $P$ suspensions, respectively. Skt was also produced abundantly from IAA in both B and BP suspensions, but not in $\mathrm{P}$ suspensions. IPA or its unidentified derivatives were shown to be related to the regulation of Skt production in BP suspensions. The interrelationship between rumen protozoa and bacteria in the production of Skt is discussed in detail in relation to Trp production from IPA via protozoa. Indole production tended to be higher in $P$ suspensions than in $B$ and $B P$ suspensions.
\end{abstract}

Anim. Sci. Technol. (Jpn.) 64 (11): 1079-1086, 1993

Key words: rumen protozoa, rumen bacteria, tryptophan synthesis, skatole formation, indolepyruvic acid

A tentative and major pathway for the metabolism of L-tryptophan (Trp) via mixed rumen microorganisms in vitro has been shown by YOKOYAMA and CARLSON ${ }^{13)}$, and HAMMOND and CARLSON ${ }^{6}$ as follows:

$$
\begin{array}{ll}
\text { Tryptophan } & \rightarrow \text { Indolepyruvic acid } \\
\downarrow & \rightarrow \\
\text { Indole } & \text { Indoleacetic acid } \rightarrow \text { Skatole }
\end{array}
$$

They also indicated that skatole (Skt), indole (Ind) and indoleacetic acid (IAA) are the major indolic metablites of Trp fermentation in

\footnotetext{
* Present address: Department of Applied Biology, Faculty of Agriculture, Iwate University, Morioka-shi 020
} 
vitro ${ }^{132}$, but they did not show any interrelationship between rumen protozoa and bacteria in Trp metabolism. In a previous paper ${ }^{12)}$, we examined the production of Ind and Skt from Trp via mixed rumen protozoa (P suspension), mixed rumen bacteria ( $\mathrm{B}$ suspension) and their combination (BP suspension), and confirmed that the the production of these compounds by $\mathrm{BP}$ suspension was almost similar to the report of YOKOYAMA and CARLSON ${ }^{13)}$. However, since IPA and IAA were not used as substrates in the previous study ${ }^{12)}$, the pathway of Trp catabolism was not confirmed. Furthermore, the IPA and IAA produced in the incubations were not determined in the previous study ${ }^{12}$. Therefore, we speculated that Ind might be the only product from Trp in $\mathrm{P}$ suspensions based on the values stoichiometrically calculated from the increase in Ind and the decrease in Trp, and based on the fact that no Skt peak was detected on the HPLC chromatograms of P suspensions. It was also noted that Skt production in BP suspension was about 5 -fold higher than that in B suspension in spite of the fact $P$ suspension never produced Skt. This problem still remains unsolved.

Recently a new method ${ }^{9)}$ for simultaneous analysis of Skt, Ind and IAA has been established by modifying a previous method ${ }^{8)}$. Thus the present study was conducted to examine Trp metabolism via $\mathrm{BP}, \mathrm{B}$ and $\mathrm{P}$ suspensions in more detail and to clarify the reason why Skt production in BP suspensions was much higher than that in $\mathrm{B}$ and $\mathrm{P}$ suspensions.

\section{Materials and Methods}

Rumen microbial suspensions: Rumen microorganisms were obtained from the rumen contents of three fistulated Japanese-Saanen goats (female, 35,35 and $45 \mathrm{~kg}$ ) fed on a daily ration consisting of lucerne (Medicago sativa) cubes ( $23 \mathrm{~g}$ dry matter $/ \mathrm{kg}$ body-weight $\mathrm{t}^{0.75}$ ) and concentrate feed (formula feed: Dairy Mix, Chubu-Shiryo, Japan; $8 \mathrm{~g}$ dry matter/kg bodyweight ${ }^{(0.75}$ ) in two equal portions given at 0900 and $1700 \mathrm{~h}$.

Rumen contents were taken from one animal for one experiment before the morning feed. Three kinds of rumen microbial suspension i.e. mixed bacterial suspensions (B suspension), mixed protozoal suspensions ( $\mathrm{P}$ suspension) and mixed suspensions of bacteria and protozoa (BP suspension), were prepared according to the method described in the previous paper ${ }^{12)}$. The $\mathrm{P}$ suspensions always included $0.1 \mathrm{mg} / \mathrm{ml}$ each of dihydrostreptomycin sulfate and penicllin $G$ potassium to suppress the biochemical activities of contaminating bacteria.

Incubation and sample treatments: Microbial suspensions $(20 \mathrm{ml})$ were anaerobically incubated, in triplicate, with and without $1 \mathrm{mM}$ each of L-tryptophan (Wako Pure Chemical Industries Ltd., Japan), indolepyruvic acid (Sigma) and indoleacetic acid (Wako Pure Chemical Industries Ltd., Japan) as a substrate in $30 \mathrm{ml}$ Erlenmeyer flasks for up to $12 \mathrm{~h}$ at $39^{\circ} \mathrm{C}$. All incubations contained $0.5 \mathrm{mg} / \mathrm{ml}$ of rice starch.

Samples $(0.5 \mathrm{~m} l)$ of the incubations for HPLC analysis for indole-derivatives were taken out at 0,6 and $12 \mathrm{~h}$-incubation periods and mixed with an equal volume of $4 \%(\mathrm{w} / \mathrm{v})$ sulfosalicylic acid, centrifuged at $27,000 \times g$ for $20 \mathrm{~min}$, filtrated $(0.45 \mu \mathrm{m}$ membrane $)$ and stored at $4^{\circ} \mathrm{C}$.

In order to determine the protozoal numbers, $0.5-\mathrm{m} l$ portions of the microbial suspensions were collected, mixed with $4.5 \mathrm{ml}$ of MFS (methylgreen-formalin-salt) solution ${ }^{11}$ and kept at room temperature.

Analytical methods: Analyses of Trp, IAA, Ind and Skt were carried out by $\mathrm{HPLC}^{9}$. Values of these compounds were expressed in differences between the figures of incubations with and without substrates. Rumen protozoa were counted with the aid of a Fuchs-Rosenthal hemacytometer. Statistically significant differences between mean values were tested using the Student's t-test. 


\section{Results and Discussion}

Metabolism of tryptophan: Fig. 1 shows the time course of a decrease in Trp and increases in IAA, Skt and Ind in BP, B and P suspensions. After $12 \mathrm{~h}$, in BP suspension, Trp decreased by $90.2 \%$, and IAA, Skt and Ind increased by $15.0,31.9$ and $4.9 \%$ in molar amounts of the added Trp, respectively. The production trends for Skt and Ind were similar to the results of the previous paper ${ }^{12)}$, but $38.4 \%$ of the added Trp was not recovered in the present experiment. Parts of the Trp might have been incorporated into microbial protein while other parts might have been present as undetermined compounds such as IPA, indoleacetoacetic acid and indolelactic acid. It was confirmed that Skt was not degraded to lower molecules even in the BP suspension during the $12 \mathrm{~h}$.

In B suspensions, Trp decreased by $40.9 \%$ and IAA, Skt and Ind increased by 24.6, 1.4 and $3.7 \%$ of the added Trp, respectively, after $12 \mathrm{~h}$. Part of the difference between the decrease in Trp and the sum of the increase in the products, $11.2 \%$, may have been incorporated as Trp into bacterial protein, and the rest may have been converted to other undetermined compounds such as IPA.

On the other hand, in P suspensions, Trp decreased by only $10.4 \%$ and only IAA and Ind increased by 2.9 and $6.7 \%$ of the added Trp, respectively, after $12 \mathrm{~h}$. In this case, the decrease in Trp was almost equal to the sum of the increases in IAA and Ind. This means that Trp was not incorporated into protozoal protein, because the protozoa in the present experiments did not grow.

Metabolism of indolepyruvic acid: Fig. 2 shows the time course of increases in IAA, Skt, Ind and Trp during incubation with IPA. IPA was not determined in the present study, because of the lack of a method. In BP suspension, the Trp concentration increased by $3.9 \%$ of the added IPA ( $1 \mathrm{mM})$ after $6 \mathrm{~h}$, but it decreased to the initial level (zero) after $12 \mathrm{~h}$. IAA increased by $24.9 \%$ of the added IPA after $6 \mathrm{~h}$, but it decreased to $13.2 \%$ after $12 \mathrm{~h}$. Skt increased with incubation time and showed $13.0 \%$ of the added IPA after $12 \mathrm{~h}$. Ind
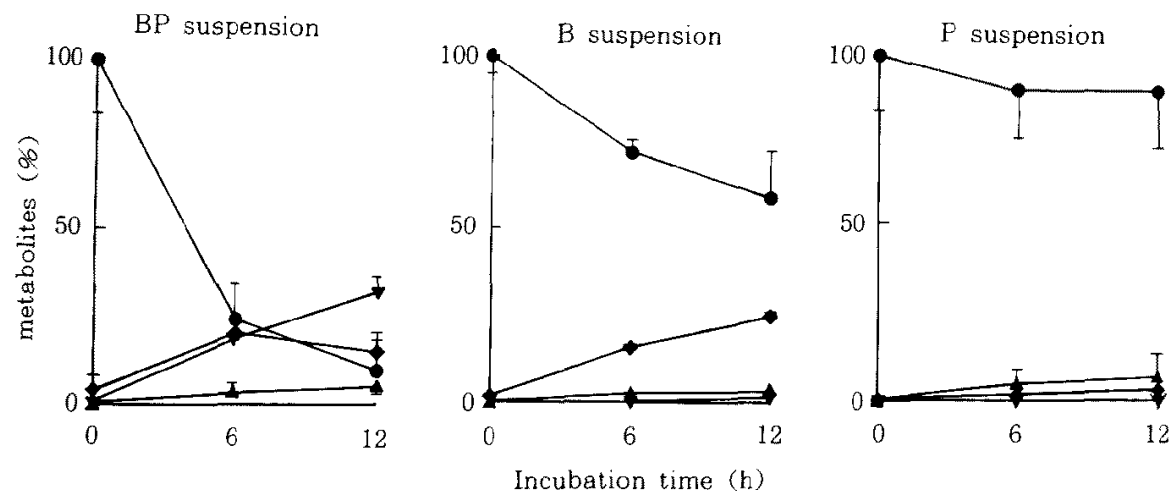

Fig. 1. Formation of indoleacetic acid $(\mathbf{\nabla})$, skatole $(\mathbf{\nabla})$ and indole $(\mathbf{\Delta})$ from tryptophan by mixed suspension of bacteria and protozoa (BP suspension), bacterial suspension (B suspension) and protozoal suspension ( $\mathrm{P}$ suspension). All values are moans with standard deviations of 9 determinations.

Means of microbial nitrogen in BP, B and $P$ suspensions were $1.92,1.26$ and $1.38 \mathrm{mgN} / \mathrm{ml}$, respectively. Protozoal composition $\left(\times 10^{4} / \mathrm{m} l\right)$ in $B P$ and $P$ suspensions were as follows, respectively: Entodiniinae, 93.5 and 199.6; Diplodiniinae, 10.2 and 11.3; Dasytricha, 1.53 and 1.73. 
equivalent to $0.5 \%$ of the added IPA was detected after $12 \mathrm{~h}$.

In $\mathrm{B}$ suspensions, Trp equivalent to $3.3 \%$ of the added IPA increased after $12 \mathrm{~h}$. IAA increased linearly with incubation time and the value after $12 \mathrm{~h}$ was $19.4 \%$ of the added IPA.
Skt and Ind were not detected.

In $\mathrm{P}$ suspensions, Trp increased by $5.6 \%$ and $12.5 \%$ of the added IPA after 6 and $12 \mathrm{~h}$, respectively. IAA also increased by 6.4 and $6.6 \%$ of the added IPA after 6 and $12 \mathrm{~h}$, respectively. Only $0.1 \%$ of Ind was detected at $12 \mathrm{~h}$
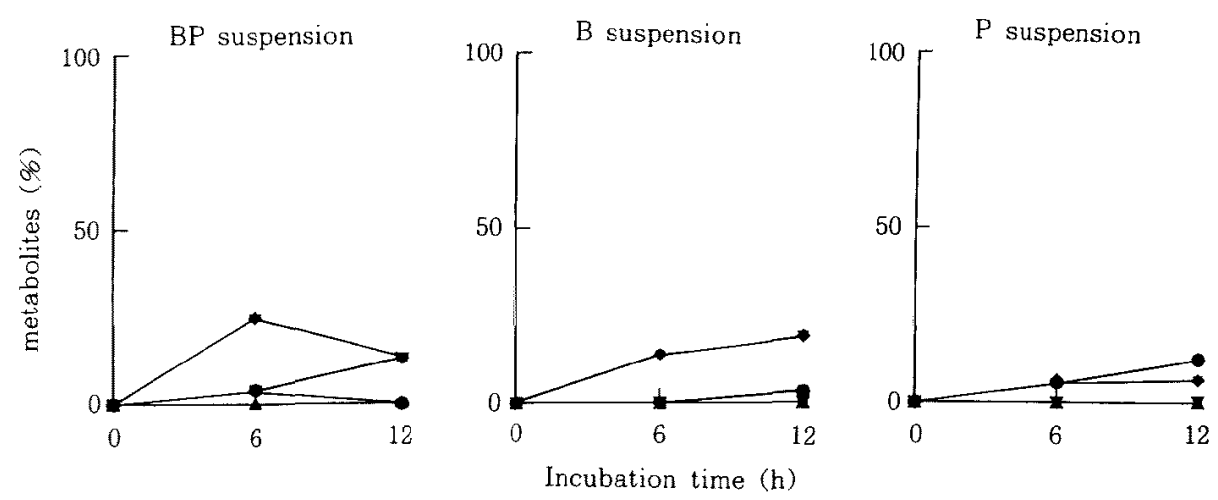

Fig. 2. Formation of tryptophan

), indoleacetic acid

, skatole ( $\mathbf{\nabla}$ ) and indole (A) from indolepyruvic acid by mixed suspension of bacteria and protozoa (BP suspension), bacterial suspension ( $\mathrm{B}$ suspension) and protozoal suspension ( $\mathrm{P}$ suspension). All values are means with standard deviations of 9 determinations.

Means of microbial nitrogen in BP, B and $P$ suspensions were $1.17,0.832$ and $1.07 \mathrm{mgN} / \mathrm{ml}$, respectively. Protozoal composition $\left(\times 10^{4} / \mathrm{m} l\right)$ in $\mathrm{BP}$ and $\mathrm{P}$ suspensions were as follows, respectively: Entodoniinae, 90.4 and 107.1; Diplodiniinae, 1.22 and 1.84 ; Dasytricha, 2.13 and 4.53 .
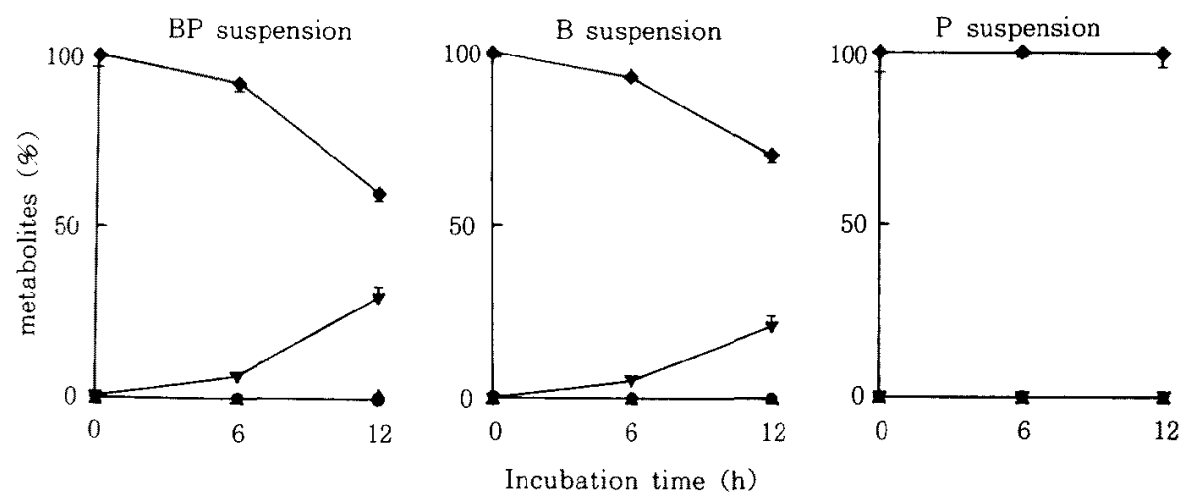

Fig. 3. Formation of tryptophan (O), skatole ( $\boldsymbol{\nabla})$ and indole $(\boldsymbol{A})$ from indoleacetate $(\boldsymbol{\Delta})$ by mixed suspension of bacteria and protozoa (BP suspension), bacterial suspension (B suspension) and protozoal suspension ( $\mathrm{P}$ suspension). All values are means with standard deviations of 9 determinations.

Means of microbial nitrogen in BP, B and $P$ suspensions were $1.05,0.93$ and $1.13 \mathrm{mgN} / \mathrm{ml}$, respectively. Protozoal composition $\left(\times 10^{4} / \mathrm{m} l\right)$ in $\mathrm{BP}$ and $\mathrm{P}$ suspensions were as follows, respectively : Entodiniinae, 55.0 and 97.8 ; Diplodininae, 2.93 and 8.35 ; Dasytricha, 1.33 and 3.82 . 
Tryptophan Metabolism by Rumen Microorganisms

and no Skt was produced.

Metabolism of indoleacetic acid: Fig. 3 shows the time course of a decrease in IAA and an increase in Skt. In $\mathrm{BP}$ and $\mathrm{B}$ suspensions, the added IAA decreased by 40.4 and $29.5 \%$ and Skt equivalent to the added IAA increased by 29.7 and $20.3 \%$ after $12 \mathrm{~h}$, respectively. The differences between the decreases in IAA and the increases in Skt in $\mathrm{BP}$ and $\mathrm{B}$ suspensions were 10.6 and $9.2 \%$, respectively. These might have been partly incorporated as Trp into microbial protein after reductive carboxylation to give IPA, followed by transamination to give $\operatorname{Trp}{ }^{1,2,7)}$, and the rest might have been present as other undetermined compounds.

In $\mathrm{P}$ suspensions, IAA remained unchanged and nothing was produced from the compound.

Production of tryptophan: Table 1 shows the production rates of Trp, IAA, Skt and Ind from Trp, IPA and IAA in BP, B and $P$ suspensions. The most interesting point in the present study was that even in $\mathrm{P}$ suspensions substantial Trp (12.5\%) was produced from IPA. As mentioned above, since the $\mathrm{P}$ suspension used in the present experiments was not a growing system, synthesized Trp accumulated as a free form in the incubations. In B and BP suspensions, there were small amounts of free Trp. In these suspensions, since microorganisms could grow, most of the Trp produced from IPA migh have been incorporated into microbial protein, or only a little Trp might have been synthesized from IPA, especially in B suspensions, because BHATIA et al. ${ }^{3)}$ demonstrated that the protozoal fraction not the bacterial fraction had strong tryptophan aminotransferase activities. The present result obtained in $\mathrm{P}$ suspension supports the results of Bhatia et al." . This is the first report in which the ability of rumen protozoal cells to synthesize Trp from IPA has actually been demonstrated, because BHATIA et al. ${ }^{7)}$ had shown only the formation of glutamic acid through transamination from Trp and many other single amino acids using crude enzymes
TabLe 1. Production rates (\%) of Trp, IAA, Skt and Ind during $12 \mathrm{~h}$ incubation ${ }^{\mathrm{a}}$

\begin{tabular}{|c|c|c|c|}
\hline Substrate & $\mathrm{BP}^{\mathrm{b}}(6 \mathrm{~h})^{\mathrm{c}}$ & $\mathbf{B}^{\mathrm{b}}$ & $\mathrm{P}^{\mathrm{b}}$ \\
\hline \multicolumn{4}{|c|}{$<$ Production rate of $\operatorname{Trp}>$} \\
\hline IPA & $\mathrm{O}^{\mathbf{d}} \quad(3.9)$ & 3. $3^{\mathrm{c}}$ & $12.5^{f}$ \\
\hline \multicolumn{4}{|c|}{$\langle$ Production rate of IAA $>$} \\
\hline Trp & $15.0^{\mathbf{d}}(20.3)$ & $24.6^{e}$ & 2. $9^{f}$ \\
\hline IPA & $13.2^{d}(24.9)$ & 19. $4^{8}$ & $6.6^{h}$ \\
\hline \multicolumn{4}{|c|}{$<$ Production rase of $S k t>$} \\
\hline $\operatorname{Trp}$ & $31.9^{d}(18.3)$ & 1. $4^{e}$ & $0^{f}$ \\
\hline IPA & $13.0^{g}(3.7)$ & $o^{f}$ & $0^{f}$ \\
\hline IAA & $29.7^{d}$ & $20.3^{h}$ & $0^{\prime}$ \\
\hline \multicolumn{4}{|c|}{$<$ Production rate of Ind $>$} \\
\hline Trp & 4. $9^{\mathrm{d}}$ & $3.7^{\mathrm{d}}$ & $6.7^{\mathrm{d}}$ \\
\hline IPA & $0.5^{e}$ & $o^{f}$ & $0.1^{8}$ \\
\hline IAA & $0.2^{\mathrm{h}}$ & $\mathrm{O}^{f}$ & $0^{f}$ \\
\hline
\end{tabular}

${ }^{a}$ Production rates: molar percentages of products to substrates, IAA : Indoleacetic acid, Ind : Indole, Skt: Skatole,

Trp : Tryptophan, IPA : Indolepyruvic acid.

${ }^{b}$ BP : mixed suspension of bacteria and protozoa,

$B$ : bacterial suspension,

$\mathrm{P}$ : protozoal suspension.

${ }^{\mathrm{c}}$ Values in parentheses are those at $6-\mathrm{h}$ incubation period.

defiglt : Means in the same row and in the same column within the same product that do not have a common superscript differ significantly $(P<0.05)$.

of rumen microorganisms.

Production of indoleacetic acid: As shown in Table $1,20.3 \%$ of the added Trp and $24.9 \%$ of the added IPA were recovered as IAA, respectively, in $\mathrm{BP}$ suspensions after $6 \mathrm{~h}$ and they decreased to 15.0 and $13.2 \%$ of those precursors, respectively, after $12 \mathrm{~h}$. In $B$ suspensions, IAA was produced from both $\operatorname{Trp}$ and IPA almost linearly with incubation time and the production rates of IAA were $24.6 \%$ of the added Trp and $19.4 \%$ of the added IPA after $12 \mathrm{~h}$. In $\mathrm{P}$ suspensions, however, the production rates of IAA were $2.9 \%$ of the added Trp and $6.6 \%$ of the added IPA after $12 \mathrm{~h}$. Protozoa seem unlikely to be very active in producing IAA. 
Production of shatole: As shown in Table 1, the production of Skt from Trp was $31.9 \%$ in BP suspension during a $12-\mathrm{h}$ incubation period in spite of the fact that a little $(1.4 \%)$ and no Skt were produced from Trp in B and $P$ suspensions, respectively. A similar phenomenon was also observed in the previous study ${ }^{12)}$. Two speculations are possible for the reason behind this phenomenon. The first one is that the presence of substantial IPA or its unidentified derivatives such as indoleacetoacetic acid and indolelactic acid in B and BP suspensions may cause bacterial systems to decrease the accumulation of Skt, because the addition of IAA produced a large amount of Skt in both B (20.3\%) and BP (29.7\%) suspensions, while the addition of IPA decreased the Skt production to zero in the B suspension and to $13.0 \%$ in the BP suspension. The second one is that in B suspension, added Trp tends to be converted to IAA via IPA as shown in Table 1, but the produced IPA may not be converted so soon to IAA, accumulates as it is or as its unidentified derivatives in the medium to a certain extent and decreases the Skt level in the medium due to an inhibitory effect of IPA against the accumulation of Skt (the first speculation). On the other hand, in BP suspen- sions, since added Trp is more quickly converted to IAA via IPA in $B P$ suspension than in $B$ suspension and since the produced IPA may be quickly transaminated by the strong action of protozoa to produce Trp as can be seen in Table 1, IPA does not accumulate in the medium and thus the Skt level increases.

In order to demonstrate the first speculation, $B$ and $B P$ suspension were incubated with IAA $(1 \mathrm{mM})$ and IAA + IPA (1 mM each) in triplicate in the same way as mentioned above. The results concering IAA and Skt are shown in Table 2. Trp and Ind were trace or zero, and were omitted from the Table. When no IPA was added to the media, added IAA decreased and Skt increased during the incubation period in both $B$ and $B P$ suspensions. On the contrary, when IPA was added to the media with IAA, the added IAA decreased more quickly than that without IPA, but Skt accumulation was much lower than that without IPA. These results support the first speculation that IPA or its unidentified derivatives tend to lower the accumulation of Skt. These results also clarified that IPA did not inhibit but stimulated the conversion of IAA. However, it is still unclear from these results whether IPA stinulated the conversion of IAA to IPA

Table 2. Effect of indolepyruvic acid (IPA) on the decrease in indoleacetic acid (IAA) and the increase in skatole (Skt) during incubation for 6 and $12 \mathrm{~h}$ in $\mathrm{B}$ and BP suspensions ${ }^{\mathrm{a}}$

\begin{tabular}{|c|c|c|c|c|c|}
\hline \multirow{2}{*}{$\begin{array}{l}\text { Changes in } \\
\text { IAA and Skt }\end{array}$} & \multirow{2}{*}{$\begin{array}{l}\text { Additives } \\
\text { to medium }\end{array}$} & \multicolumn{2}{|c|}{ B suspension } & \multicolumn{2}{|c|}{ BP suspension } \\
\hline & & $6 \mathrm{~h}$ & $12 \mathrm{~h}$ & $6 \mathrm{~h}$ & $12 \mathrm{~h}$ \\
\hline \multirow[t]{2}{*}{$\begin{array}{l}\text { IAA decrease, } \\
\mathrm{nmol} / \mathrm{ml},(\%)^{\mathrm{b}}\end{array}$} & IAA only & $92(8.8)$ & $106(10,2)$ & $137(13.5)$ & $222(21.8)$ \\
\hline & IAA + IPA & - & $147(14.2)$ & $178(17.7)$ & $261(26.0)$ \\
\hline \multirow[t]{2}{*}{$\begin{array}{l}\text { Skt increase, } \\
\text { nmol } / \mathrm{ml},(\%)^{\mathrm{b}}\end{array}$} & IAA only & $15(1.4)$ & 115 (11.0) & $50(4.9)$ & $174(17.1)$ \\
\hline & IAA + IPA & $7(0.6)$ & $18(1.8)$ & $5(0.5)$ & $83(8.3)$ \\
\hline
\end{tabular}

\footnotetext{
${ }^{a} \mathrm{~B}$ suspension: bacterial suspension

BP suspension : mixed suspension of bacteria and protozoa.

${ }^{b}$ Values in parentheses are percentages of decrease in IAA and increase in $\mathrm{SkL}$ to the added IAA.
} 
through reductive carboxylation. To answer these problems and to demonstrate the second speculation, we need to establish a determination method for IPA and its unidentified derivatives. In any case, it was revealed that the excellent ability of rumen protozoa to transaminate IPA in order to give Trp led to stimulating Skt accumulation.

Production of indole: Ind production from Trp in $\mathrm{P}$ suspension tended to be higher than in $B$ and BP suspensions (Table 1), which coincided with the result of the previous paper ${ }^{12}$. It is known that Ind is produced from Trp by the tryptophanase of some bacteria, ${ }^{4,5)}$ and rumen protozoa ${ }^{10)}$. The production of Ind from IPA and IAA, therefore, may mean the precedent production of Trp from these compounds, but the amounts of Ind were too small to discuss in the present study.

\section{Acknowledgements}

The authors are grateful to Dr. H. OGAwA, Associate Professor at Miyazaki University, for inserting permanent rumen fistula into goats, and to Dr. J. R. LING, University College of Wales (UCW), Aberystwyth, for valuable comments.

The present study was financially supported by the Grant-in-Aid for Scientific Research (C) (1990-1992), and in part by a research grant from Kaken Pharmaceutical Co., Ltd.

\section{References}

1) Allison, M.J. and I.M. Robinson, Tryptophan biosynthesis from indole-3-acetic acid by anaerobic bacteria from the rumen. Biochem. J., 102: 36-37. 1967.

2) AlLison, M.J. Biosynthesis of amino acids by ruminal microorganisms. J. Anim. Sci., 29 : 797-807. 1969.

3) Bhatia, S.K., K. Pradhan and R. Singh, Microbial transaminase activites and their relationship with bovine rumen metab- olites. J. Dairy Sci., 62 : 441-446. 1979.

4) Boyd, W.L. and H.C. Lichstein, The effect of carbohydrates on the tryptophanase activity of bacteria. J. Bacteriol., 69: 584589. 1955.

5) Burns, R.O. and R.D. Demoss, Properties of tryptophanase from Escherichia coli. Bioshim. Biophys. Acta, 65 : 233-244. 1962.

6) Hımmond, A.C. and J.R. CARlson, Inhibition of ruminal degradation of $\mathrm{L}$ tryptophan to 3-methylindole, in vitro. $\mathrm{J}$. Anim. Sci., 51 : 207-217. 1980.

7) Kristensen, S., Ruminal biosythesis of aromatic amino acids from arylacetic acids, glucose, shikimic acid and phenol. Brit. J. Nutr., 31 : 357-365. 1974.

8) Nagasawa, T., H. Ueda and R. Ononera, Rapid determination of tryptophan, indole and skatole in rumen fluid by HPLC. Jpn. J. Zootech. Sci., 59: 93-94. 1988.

9) OKuUchi, K., T. Nagasawa and R. ONODERA, A modified determination of tryptophan, indoleacetate, indole and skatole in rumen fluid using HPLC. Anim. Sci. Technol. (Jpn.). 63 : 708-711. 1992.

10) OkuUchi, K., T. Nagasawa and R. ONODERA, Characteristics of tryptophanase (crude enzyme) of mixed rumen ciliate protozoa. Anim. Sci, Technol. (Jpn.). 63 : 1038-1041. 1992.

11) Onodera, R., H. Yamaguchi, C. Eguchi and M. Kandatsu, Limits of survival of the mingled rumen bacteria in the washed cell suspension of rumen ciliate protozoa. Agric. Biol. Chem., $41: 2465-2466.1977$.

12) Ononera, R., H. Ueda, T. Nagasawa, K. OKuUchi, S. Chaen, M. Mieno and H. KUDO, In vitro metabolism of tryptophan by ruminal protozoa and bacteria: The production of indole and skatole and their effects on prtozoal survival and VFA production. Anim. Sci. Tchnol. (Jpn.). 63 : 23-31. 1992.

13) Yokoyama, M.T. and J.R. Carlson, Dissimilation of tryptophan and related indolic compounds by ruminal microorganisms in vitro. Appl. Microbiol., 27: 540-548, 1974. 


\section{In vitroにおけるルーメン微生物のトリプトファン代謝 :}

$$
\text { ルーメンプロトゾアとバクテリアの相互関係 }
$$

\section{奥内勝也・長澤孝志 ${ }^{*} \cdot$ 富田純史・小野寺良次}

宮崎大学農学部, 宫崎市 889-21

本研究は，トリプトファン (Trp)、インドールピルビン酸（IPA）およびインドール酷酸（IAA） を基質としてルーメン内のプロトゾア（P)，バクテリア（B）およびそれらの混合微生物（BP）の狀 濁波による上記の化合物の代謝を in vitroで榆討することを目的とした，ルーメン微生物は，1日に 2 问アルファルファキューブと濃厚飼料を給与しているフィスチュラ装着山羊加ら採取した. 12 時間 培養後，P奬濁液では IPA から多量のTrpがつくられ，培地中に蓄積したが，IAA からは Trp は つくられなかった，B拉よび BP 獎濁液ですTrp の合成は起っているはずであるが，これらの系では 微生物の潧殖にそれが使われたためか，培地中には蓄皘しなかった，B および BP 惩濁液では Trpお よび IPA から多量の IAA がつくられたが，P獎濁液ではIAA はあまりつくられなかった，Trpか

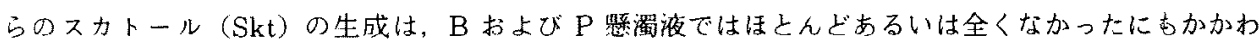

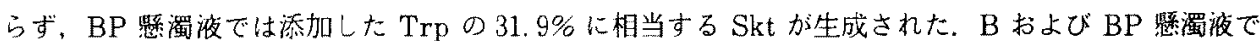
はIAAからも多くの Skt が生成されたが，P䣨蜀液では全く生成されなかった，IPAまたはその末 同定誘導体は，BP 䈍濁液における Skt 生成の調節に関与寸ることが示された。プロトゾアによるIPA からの Trp 合成との関連から, Skt の生成におけるバクテリアとプロトゾアの相互関係について考察

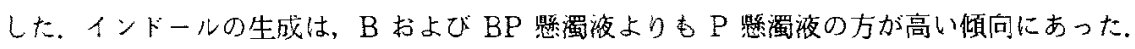

日童会報，64(11)：1079-1086，1993

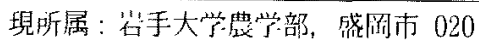

